\title{
A Persuasive Peace: Syrian Refugees' Attitudes towards Compromise and Civil War Termination*
}

\author{
Accepted for publication at Journal of Peace Research \\ Kristin Fabbe ${ }^{\dagger}$ Chad Hazlett $\frac{\ddagger}{\ddagger}$ \& Tolga Sinmazdemir ${ }^{\S}$
}

25 October 2018

(Word Count: 9,953)

\begin{abstract}
Civilians who have fled violent conflict and settled in neighboring countries are integral to processes of civil war termination. Contingent on their attitudes, they can either back peaceful settlements or support warring groups and continued fighting. Attitudes toward peaceful settlement are expected to be especially obdurate for civilians who have been exposed to violence. In a survey of 1,120 Syrian refugees in Turkey conducted in 2016, we use experiments to examine attitudes towards two critical phases of conflict termination - a ceasefire and a peace agreement. We examine the rigidity/flexibility of refugees' attitudes to see if subtle changes in how wartime losses are framed or in who endorses a peace process can shift willingness to compromise with the incumbent Assad regime. Our results show, first, that refugees are far more likely to agree to a ceasefire proposed by a civilian as opposed to one proposed by armed actors from either the Syrian government or the opposition. Second, simply describing the refugee community's wartime experience as suffering rather than sacrifice substantially increases willingness to compromise with the regime to bring about peace. This effect remains strong among those who experienced greater violence. Together, these results show that even among a highly pro-opposition population that has experienced severe violence, willingness to settle and make peace are remarkably flexible and dependent upon these cues.
\end{abstract}

Keywords: civil war, violence, civilian attitudes, peace, framing experiments

*Acknowledgments: We thank participants of Empirical Studies of Conflict and other workshops and seminars for their feedback on earlier versions. Above all, we thank survey participants for graciously providing their time and energy to discuss their experiences with us.

†Business, Government, and International Economy Unit, Harvard Business School. kfabbe@hbs.edu (Corresponding)

¥Department of Political Science, UCLA. chazlett@ucla.edu

$\S$ Department of Political Science and International Relations, Bogazici University. tolga.sinmazdemir@boun.edu.tr 


\section{Introduction}

Terminating civil wars, let alone proceeding to reconcile and reintegrate civilian communities to realize lasting peace and avoid future conflict, poses many seemingly insurmountable challenges. The Syrian conflict is a case in point. Ceasefires have been short-lived, millions have been displaced, and a durable peace settlement has proven elusive. Do Syrian refugees - and especially those who have experienced violence firsthand - support a ceasefire with the incumbent regime? Under what conditions will refugees consider a peace agreement that keeps Assad in power? When will they reject these types of compromise and instead demand nothing short of fully removing the incumbent regime?

These are critical questions, for civilians who have fled violence and settled in neighboring countries can be integral to ending or prolonging conflicts. Refugees can either back ceasefires and peaceful settlements or support warring groups and continued fighting (Salehyan \& Gleditsch, 2006; Salehyan, 2007, 2009). Furthermore, as surveys with Syrian refugees in Turkey show, the majority want to return home and continue their lives in postcivil war Syria (Erdogan, 2017). This makes their views integral to a durable settlement of the conflict, as they will be in a position to provide recruits, support, and information (or to withhold these things) to future armed groups. Finally, Syrians in Turkey are sending remittances home, mostly to Aleppo and Damascus (Dean, 2015). These diaspora remittance flows can affect civil war onset and recurrence, depending on whether remittances are sent for peaceful purposes (Regan \& Frank, 2014) or to finance rebel groups and terrorism (Collier \& Hoeffler, 2004; Elu \& Price, 2012).

In this article, we examine Syrian refugees' attitudes towards civil war termination. Refugees are the victims of conflict, and victimization in war has been found to produce a strong desire for revenge in contexts as diverse as the Balkans (Petersen, 2002), El Salvador (Wood, 2003), Turkey (Tezcür, 2016), Greece (Kalyvas, 2006) and Spain (Balcells, 2012), spanning time and even generations. Although such a reaction may be understandable and even intuitive, do the victimized indeed react in this way? And, if so, how obdurate are their attitudes to change? In contrast to the work cited above, we treat these attitudes as potentially flexible rather than assuming that they are forged definitively as a result of wartime experiences. Using a new survey of 1,120 Syrian refugees in Turkey conducted in the fall of 2016, we examine two potentially powerful modifiers of attitudes towards willingness to stop fighting, compromise, and make peace: (a) who is responsible for proposing an agreement, particularly whether it is a Syrian civilian or Syrian armed actors; and (b) how wartime experiences with violence are characterized - as sacrifice or as suffering.

The question of whether or not refugees' views - even when forged amid traumatic experience - are indeed obdurate and vengeful has important implications for understanding how attitudes are shaped in conflict settings as well as practical implications for bringing about peace. The overwhelming majority of the refugees in Turkey have fled Syria as a result of the attacks by Assad's forces (Kirişci, 2014), and therefore are believed to be pro-opposition. In fact, about $70 \%$ of respondents in our sample see the opposition groups in Syria as their closest representative, with the remainder saying that no one represents them. There have been numerous attempts to bring the warring parties to comprise via a negotiated solution, the most significant of which was the Annan plan. The plan failed, it 
is argued, because the already enormous scale of death and destruction made opposition groups unwilling to compromise with the Assad regime (Lynch, 2016).

We find that even among refugee communities in Turkey - groups that have fled extreme incumbent violence, overwhelmingly support Assad's removal, and tend to identify with the opposition - willingness to accept ceasefires, peaceful negotiations, and settlements that leave Assad in power are contingent upon who advocates them and how past experiences of violence are framed. Specifically, refugee civilians in our sample are 11 to 14 percentage points more likely to agree with a ceasefire and peace process arrangement when proposed by Syrian civilians as opposed to Syrian military commanders from either the regime or the opposition, suggesting a special signaling value of civilian proposers of peace. In practice, it also suggests that armed actors - from either side - may not be the most persuasive in convincing traumatized civilian communities to compromise. Second, we find that framing refugees' collective experiences with violence as suffering rather than sacrifice increases support for a peace agreement that involves compromising with the regime by 14 to 18 percentage points. This holds whether the suffering is described within the family or the community, and it holds or is magnified among those who come from neighborhoods that have experienced direct violence. Together, these findings provide two initial but powerful examples of how small changes (1) in how peace processes are proposed or (2) in how conflict narratives are constructed, can widely shift individual attitudes in ways that either help or hinder compromise, and thus war termination via negotiated settlement.

\section{Violence and the role of refugees in civil war termination}

Ceasefires and negotiated peace settlements have become increasingly important to conflict termination in recent decades. Whereas during the cold war the vast majority of civil wars ended in military victory (72\%), in the 1990s, only $31 \%$ of wars ended in a military victory, with the number decreasing to $11 \%$ between 2000 and 2007 (Hartzell, 2018). ${ }^{1}$ Although negotiated settlements became the norm, their flaws and weaknesses also became increasingly apparent. For example, Toft (2009) argues that the focus on negotiated settlements is problematic in that such settlements are more likely to result in repeated outbreaks of violence than outright victories. Such settlements often break down because of disagreements over mutual disarmament and political power sharing (Fearon \& Latin, 2008) and/or because spoilers and veto players can spark a return to conflict (for example see Kydd \& Walter (2002); Stedman (1997); Newman \& Richmond (2006)). Recent research suggests that civil conflicts involving Jihadi groups are even less likely to end successfully via negotiated settlement (Kalyvas, 2018).

To better understand the mechanisms behind these failures, the study of conflict termination has matured to incorporate the subcomponents of negotiated settlements - including the nuances of ceasefires and peace agreements - into the broader scholarly agenda (Åkebo, 2016; Karakus \& Svensson, 2017). Nonetheless, we still lack micro-level studies of civil-

\footnotetext{
${ }^{1}$ There is some evidence to suggest that, as old cold-war rivalries resurface and international norms change, military victories may be making a resurgence (Morjé Howard \& Stark, 2017).
} 
ians' attitudes towards conflict termination arrangements - and especially the attitudes of civilians who have been displaced from the war theater but wish to return. This is problematic, as research has shown that refugee populations can be an important source of conflict diffusion and prolongation (Salehyan \& Gleditsch, 2006; Salehyan, 2007, 2009). If we wish to understand the feasibility of compromise with the incumbent regime as well as the long-term viability of ceasefires and peace settlements in a given conflict, the views of those who have fled across the border but remain deeply connected to war outcomes cannot be ignored.

\subsection{Attitudinal responses to violence}

One would expect that refugees' attitudes towards war termination will be shaped, at least in part, by the violence they experienced during the war. A burgeoning scholarship on civilian responses to violence acknowledges that attitudes are shaped by traumatic experiences. This body of research, however, remains divided on whether such experiences result in more hostile and war-prone vs. more pro-social, conciliatory and peaceful attitudinal dispositions. For example, Hirsch-Hoefler et al. (2016) find that exposure to terrorism and political violence in Israel 'hardens hearts' against peace efforts. Focusing on the same conflict, Grossman, Manekin \& Miodownik (2015) show that exposure to high-intensity combat hardens attitudes towards the rival and reduces support for negotiation and compromise among Israeli ex-combatants. ${ }^{2}$ On the other side of the ledger, Tellez (2018) employs observational studies in Colombia, finding that areas more exposed to FARCrelated violence were more supportive of the referendum on a peace accord with FARC. A quasi-experimental study of violence faced by Darfurian refugees similarly finds that those exposed to greater violence within individual villages hold more pro-peace attitudes (Hazlett, Hazlett). ${ }^{3}$

Setting aside the directional effects (pro-peace and compromising vs. anti-peace and vengeful) of exposure to violence, one might also expect refugees' attitudes - and especially attitudes about war termination - to be obdurate since they were forged in a context characterized by traumatic experiences, including displacement, upheaval and worse. Still, conflicts are partly battles over how people should think about the experience of war - particularly gains and losses, both in the past and the future (Kalyvas, 2006; Christia, 2012). As with other processes of attitude-formation, how individuals understand the wages of war (Scheufele \& Iyengar, 2012) and the advantages of conflict termination may depend on

\footnotetext{
${ }^{2}$ Examining possible mechanisms for this type of finding, Canetti et al. (2017) find that exposure to political violence increases threat perception, psychological distress, and decreases support for political compromise. Petersen (2002), who also homes in on mechanisms, uses emotional motivations to explain the attitudes and behaviors of victimized communities that are driven to take up arms or otherwise support violence against their perpetrators.

${ }^{3} \mathrm{~A}$ rich emerging literature also focuses on the effects of violence on a variety of outcomes including community engagement, trust, and cooperation. Many of these studies find that violence produces 'pro-social' behavior (see Bauer et al., 2016 for a recent review). However, as noted in Bauer et al. (2016), these apparently pro-social behaviors are often parochial, directed towards the in-group members. The effects of violence on a broader desire for peace and harmony with other groups remains unclear. For example, while Getmansky, Sinmazdemir \& Zeitzoff (2018) find that Turkish citizens in provinces with past history of violence have warmer attitudes towards Syrian refugees, the article in this volume by Ghosn, Braithwaite \& Chu (2019) does not find evidence that past exposure to violence correlates with more positive sentiments towards Syrian refugees in Lebanon.
} 
how they are contextualized or framed. For instance, in this volume, Schon (2019) argues that refugees' migration decisions in the face of violence may depend on whether their experience of violence can be reconciled with an existing narrative about security.

The ability to manipulate attitudes by varying how a piece of information is presented is well known to scholars of public opinion (see e.g. Hurwitz, 1989; Maoz, 1990; Scheufele \& Tewksbury, 2007; Zaller, 1992). To this end, much work also has been done to demonstrate how framing can shift the attitudes of Americans or other publics on the home-front. For example, Boettcher III \& Cobb (2009) examine whether framing US war casualties in Iraq to American subjects as a 'sacrifice' influenced individuals' commitment to continuing the conflict. They find that the sacrifice frame strengthens hawks' commitment, but weakens that of doves. In a similar study, Schott, Scherer \& Lambert (2011) find that the framing effect of stating war casualties is moderated by the attainability of the military goal.

Can similar framing effects be found among civilian refugees who have recently fled an active theater of war? Or are refugees' attitudes firmly fixed by their experiences? Given the logistical and security challenges associated with such research, there are few empirical studies of civilian attitudes toward combatants and/or peace settlements during wartime, and even fewer examining the strength of various framing effects that might influence these attitudes. This is problematic because framing effects are expected to be weaker in issue domains with high salience, as we would expect to be the case with attitudes about war termination among refugees. In one notable exception, Corstange \& York (2018) recently conducted a survey experiment with Syrian refugees in Lebanon to investigate 'how the different war narratives spun by the government and the opposition affect how people view the causes of war.' (445) They find a sectarian framing effect 'but only for some people, and only when sheltered from discursive competitors,' (450) and conclude that 'elites are more constrained in their ability to frame than we commonly suppose' (450). Conversely, in prior work on 'intractable conflicts' where opinions are also assumed to be strong and fixed, Gayer et al. (2009) find that emphasizing possible future losses increases the chances that Israeli participants will consider new peace options. We seek to build on this nascent literature by studying how subtle shifts in the framing of proposed agreements (by varying the proposer) or in the community's experiences with violence (as sacrifice or suffering), can alter attitudes regarding compromise towards war termination.

\subsection{Who proposes peace?}

One potentially powerful modifier of attitudes about conflict termination lies in cues about the identity of who exactly is speaking out in favor of compromise and negotiation. Specifically we examine whether it matters if it is a military elite actor (either from the regime or opposition) or Syrian civilians who proposes a ceasefire. On one hand, military elites may be more persuasive as spokespeople for peace, because they have more immediate control over the use of violence, and so their advocacy of a ceasefire might be seen as more valuable. Indeed, much of the political science research on civil conflict assumes that militarized elites have control over civilians and their expressed attitudes toward allies and enemies. As such, they are considered key actors who ultimately determine civilians' positions on who to ally with, who to fight, and who to make peace with. (see e.g. Christia, 
2012; Varshney, 2003). It follows that military elites are therefore also typically considered integral to securing durable peace settlements. Military elites are the ones at the negotiating table, with much effort devoted to convincing them to lay down arms and accept settlements such as power-sharing agreements.

On the other hand, there are several theoretical reasons to expect that civilian refugees in our sample may find other Syrian civilians, broadly defined, to be more persuasive as spokespeople for compromise, negotiation and peace. First, 'informational social influence' can be one powerful source of persuasion (Cialdini, 2001), in which a person who is otherwise unsure of the correct behavior looks to others for information. Among factors that may influence this process, the similarity of the messenger to the person receiving the message can increase persuasive impact (e.g. Turner \& Oakes, 1998). Whether our respondents imagine a given Syrian civilian to be part of their community or not, they surely see them as more similar in position and background than military elites. Relatedly, 'self-categorization' theory emphasizes that when individuals identify with a particular group (here, as Syrian civilians as opposed to military elites), 'sources' in that group (here other civilians) can obtain social influence on the 'target' (here, our respondent)(e.g. see Turner \& Oakes, 1998; Turner, 1991). In short, such theories would predict that a ceasefire proposal made by other Syrian civilians would be more persuasive simply because those civilians have much more in common with our respondents than do military elites: if other civilians - who may have faced similar hardships as a result of the war - are willing to advocate a compromise via a ceasefire, this may persuade the respondents that they should do the same.

Second, cues showing that other Syrian civilians support a ceasefire could make respondents feel that it is socially permissible and safe to speak out in favor of conflict termination. Such cues might be particularly salient in communities that would otherwise impose an expectation to seek revenge in response to past violence. ${ }^{4}$ Even without cultural, emotional, or psychological dimensions, immediate security concerns alone may force respondents to care about what other civilians think. Community members may worry about informants, and in our case, especially informants working for the opposition. These informants can provide important information to their patrons (opposition leaders and fighters), including the identity of regime sympathizers (see e.g. Kalyvas, 2006). Syrian refugees in Turkey, many of whom fled from opposition held territory, may feel obligated to show full-throated support for putative, pro-opposition objectives, and thus express a refusal to compromise with the Syrian government for fear of raising suspicion that they are regime sympathizers. Only if they believe that compromising with the regime would be seen as acceptable in the wider Syrian community - such as when another civilian proposes it - could they show support.

Furthering this 'permissibility' logic, we also consider the possibility that some types of civilians may have greater authority than others in 'making it okay to support peace'. In particular, we consider those who have been permanently injured, and thus must suffer on an ongoing basis as a result of that loss. Such individuals may be expected to show an

\footnotetext{
${ }^{4}$ More broadly, this has been theorized in the form of the 'culture of honor' (Nisbett \& Cohen, 1996), which proposes that in some cultures, members are socially obligated to show a desire for vengeance.
} 
understandable desire for vengeance, but if they instead speak out in support for peace, it may strongly signal that doing so is permissible. We thus examine whether a civilian individual who has lost a limb due to regime violence may be even more persuasive than an unspecified Syrian 'civilian' in influencing our respondents' stated acceptance of peace.

On a more pragmatic note, the question of the identity of the spokesperson for a ceasefire and eventual war termination is also directly relevant in the ongoing efforts to end the civil war in Syria. First, since the third round of the Geneva peace talks between the Syrian government and the opposition, UN Special Envoy Steffan de Mistura has consulted civil society organizations such as the Women's Advisory Board, the Civil Society Support Room, and the Experts Room (Alzoubi, 2017). However, these civil society organizations have been asking for a more extensive role in peace talks (Zena, 2017). Second, civilians have been actively involved in the negotiation of local ceasefires in various areas of conflict in Syria as well (Araabi \& Hilal, 2016). It is also worth noting that these civilian negotiators are not necessarily elites distant from our respondents. These civilian actors include a mix of local notables and activists as well as Syrians with different occupations, such as doctors and teachers. About $3 \%$ of our sample also consists of teachers, suggesting that civilian negotiators do not necessarily have backgrounds and qualities that are drastically different from those of our respondents. The impact of civilians, and especially of local notables, in these negotiations have been arguably both positive and negative (see e.g. Karakus \& Svensson, 2017; Araabi \& Hilal, 2016). Our experiments shed light on this critical issue by studying whether the inclusion of Syrian civilian actors in ceasefire processes makes these agreements more acceptable to Syrian refugees, many of whom hope to return home.

\subsection{Framing losses: Sacrifice vs. suffering}

In an interview with the Guardian, Free Syrian Army commander, Abu al-Farouq, said: 'Any truce with the regime is unacceptable after all the sacrifices we made.' ${ }^{5}$ By contrast, in the fourth round of Geneva peace talks, while addressing representatives of Assad's government and the opposition, UN Special Envoy de Mistura used a different framing, 'The Syrian people desperately all want an end to this conflict and you all know it [...] They are waiting for a relief from their own suffering and dream of a new road out of this nightmare to a new and normal future in dignity. ${ }^{6}$ These two examples illustrate use of the terms 'sacrifice' and 'suffering' by actors in the Syrian conflict to argue for or against war termination. Are they in fact persuasive? In this section we turn to theoretical motivations for our second experiment, which examines how the framing of wartime experiences as sacrifice or as suffering influences willingness to settle in order to achieve peace.

Beginning with the term 'sacrifice', we consider first 'escalation of commitment' (or the sunk cost fallacy), a concept that has been widely invoked in numerous disciplines with roots in prospect theory ${ }^{7}$ and, in the context of social groupings, in social identification

\footnotetext{
${ }^{5}$ Emphasis added. Available at https://www.theguardian.com/world/2015/mar/11/ war-in-syria-how-my-life-has-changed

${ }^{6}$ Emphasis added. Available at https://www.reuters.com/article/us-mideast-crisis-syria-un/ syrias-warring-sides-face-off-as-u-n-tells-them-end-the-nightmare-idUSKBN16217C

${ }^{7}$ For a general overview of prospect theory see: Kahneman \& Tversky (1984). For a review of prospect theory in political science see: McDermott (2004); Levy (1992).
} 
theory (see e.g. Dietz-Uhler, 1996). Individuals do not wish to seek their past behaviors 'wasted' by giving up on the purpose for which they originally acted, even when continuing the same behavior is irrational (Staw, 1976). Rather, when faced with losses, they may double down on their original commitment rather than abandon it (Arkes \& Blumer, 1985; Thaler \& Johnson, 1990; Weber \& Zuchel, 2005). These concepts are particularly relevant in a conflict setting like the Syrian Civil War, where the losses incurred after an uprising may be well beyond the scale that any of the original participants imagined. Accordingly, we expect that the word 'sacrifice' will have the effect of engaging a sunk-cost type of thinking: e.g. so much has been invested in this conflict, how could one give up and settle with Assad now?

By comparison, the term 'suffering' also implies a loss, but emphasizes the pain of that loss. As argued in earlier work on 'war-weariness', those who feel the painful repercussions of violence most strongly may also be inclined to avoid future violence, to compromise and bring about peace. ${ }^{8}$ Moreover, by priming loss without referencing the goals for which that loss was made, the word 'suffering' is less likely to engage sunk-cost reasoning compared to 'sacrifice'. Thus, we expect the 'suffering' prime to trigger thinking along the following lines: we have faced so much hardship already, perhaps ending this conflict is the best thing for the community.

Accordingly, we examine reactions to loss framed as Community sacrifice, or as Community suffering. We were further interested in whether characterizing losses as community suffering may be too broad or remote a prime, and whether there might be a stronger reaction to framing the conflict in terms of suffering within one's family itself. We thus also consider a Family suffering frame. ${ }^{9}$

\section{Methods}

Our sampling strategy involved three stages, described in the Appendix. The vast majority of Syrian refugees in Turkey live outside refugee camps in urban neighborhoods. We sampled Turkish provinces with the highest number of Syrians present: Istanbul, Hatay, Sanliurfa and Gaziantep.The resulting sample includes 1,120 out-of-camp Syrians, making this survey, to our knowledge, the largest and most comprehensive survey of political attitudes of Syrian refugees in Turkey. While showing some variation across provinces, our response rate was $34 \%$.Figure 1 shows the geographic distribution of the sample by Syrian governorate. Figure 2 shows the distribution of key demographic characteristics. Overwhelmingly, individuals reported leaving Syria due to security concerns, with $80 \%$ leaving in 2013 or later when the fighting became more severe, especially in and around Aleppo.

Finally, Experiment 1 and Experiment 2 each have four conditions, and random assignment is done with equal probability of receiving each prime, independently between the

\footnotetext{
${ }^{8}$ For a review of the war weariness literature, see e.g. Levy \& Morgan (1986), though it has been generally applied to international conflicts and study of war recurrence or initiation. More recent empirical findings supportive of a 'weary' effect of violence on attitudes toward peace in the context of civil conflict can be found in Tellez (2018) and Hazlett (Hazlett).

${ }^{9}$ In principal we could have added a framing around family level sacrifice as well, but given power limitations we did not wish to add a fifth condition.
} 


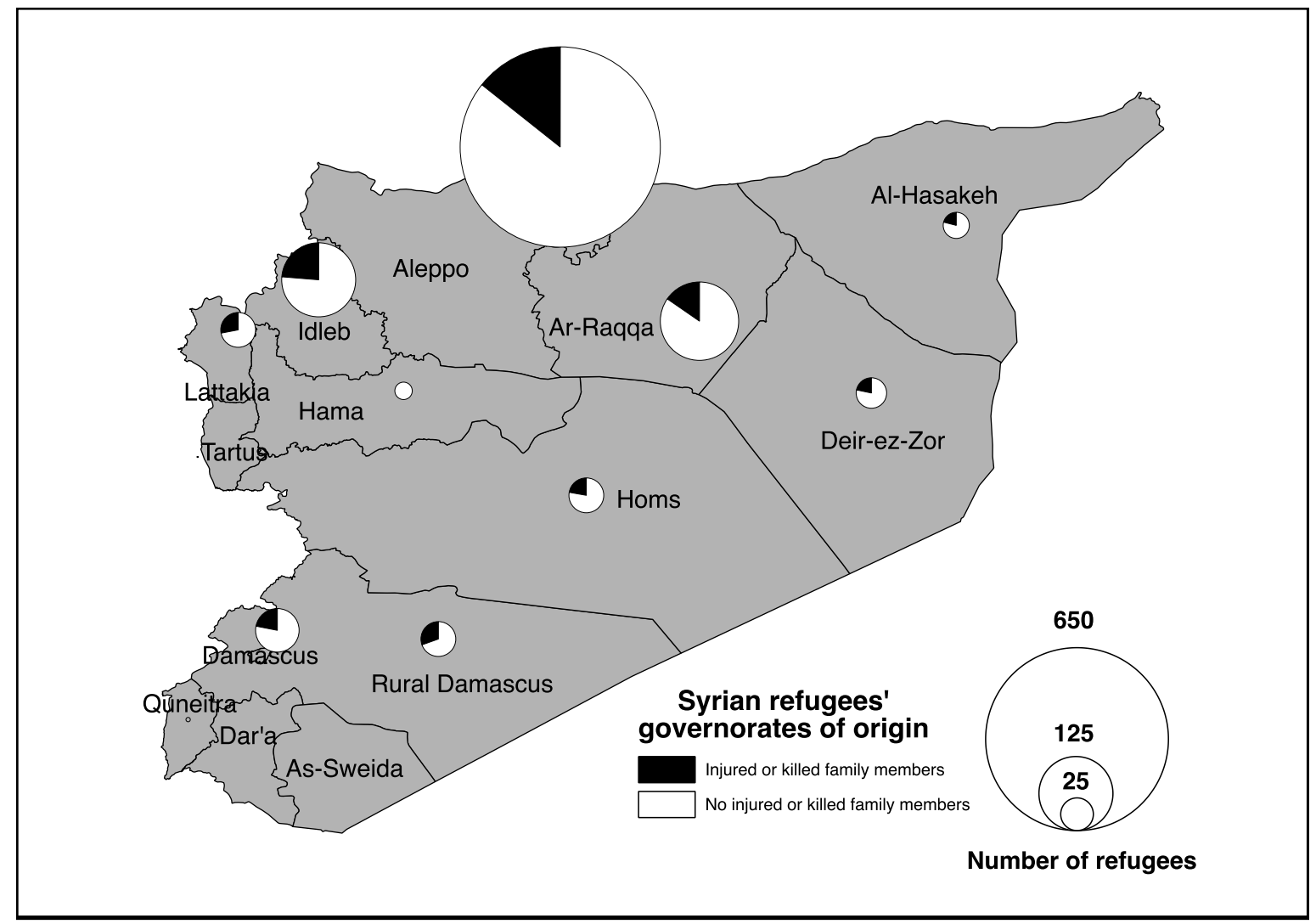

Figure 1. Locations of origins and barrel bombing incidence
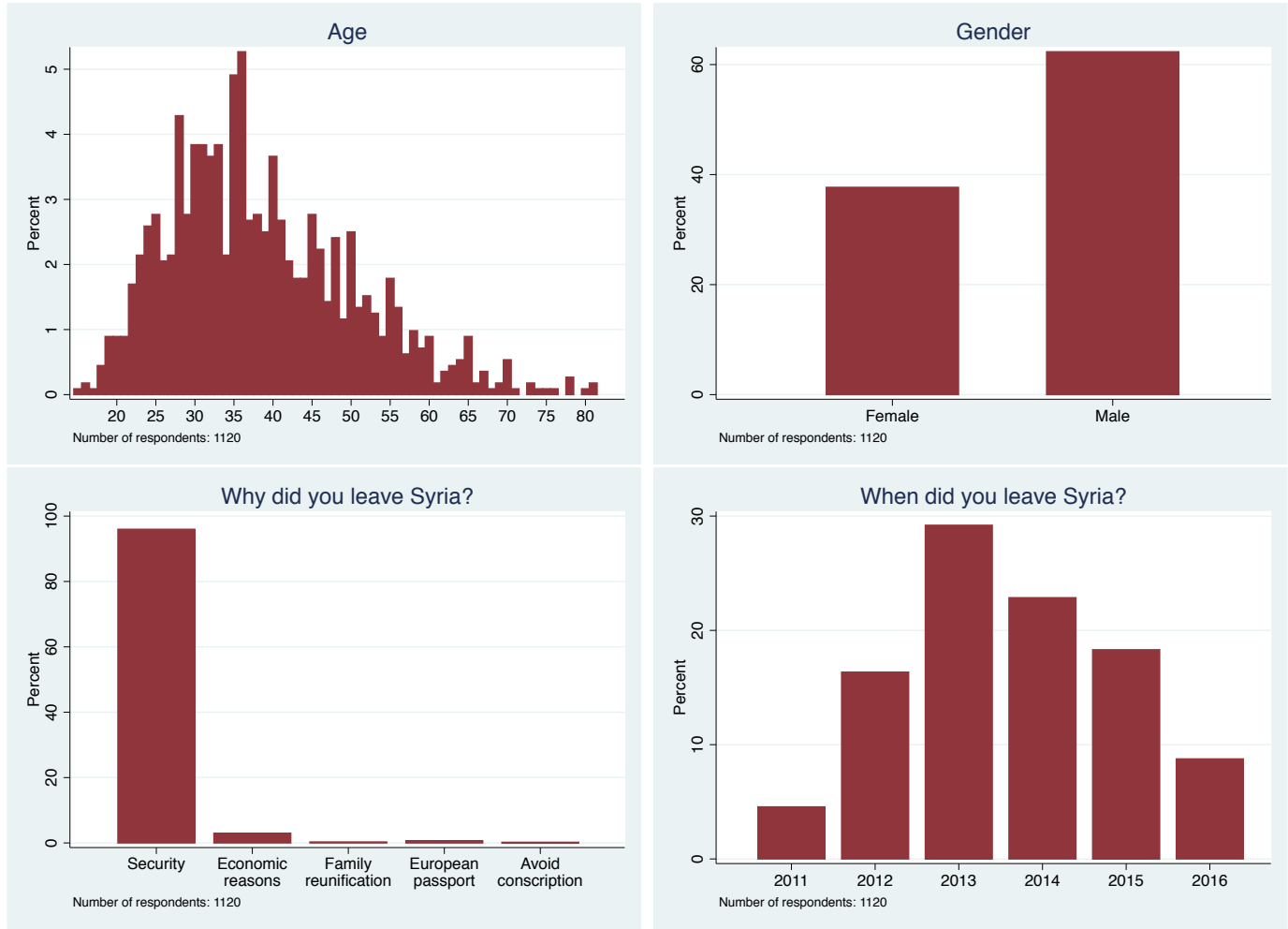

Figure 2. Key demographic descriptives

Key demographic statistics: Age distribution (top left), gender distribution (top right), stated reason for leaving Syria (bottom left), and year departing Syria (bottom right). 


\subsection{Experiment 1: Identity of a ceasefire proposer}

Experiment one examines how the identity of who is proposing a conflict termination arrangement (here, a ceasefire and return to peaceful negotiation) affects respondents' willingness to accept it, and particularly whether a Syrian civilian proposer engenders higher agreement than those of armed actors on either side. To explore this, we randomly assigned each respondent to a condition in which the person proposing a ceasefire could be:

1. A commander of the Syrian Army

2. A commander from the Syrian opposition

3. A civilian non-combatant who has lost a limb during the war

4. A civilian non-combatant

Participants are then prompted with a statement about a hypothetical ceasefire, saying that the assigned actor 'spoke out in favor of laying down arms and returning to a nonviolent political process.' We then ask respondents about their level of agreement with the statement (Strongly disagree, Somewhat disagree, Neutral, Somewhat agree, Strongly agree).

\subsection{Experiment 2: Framing of wartime experiences}

Experiment two is designed to determine whether the willingness to compromise for peace (here, accept a peace agreement that includes a role for the Assad regime in governance, versus demanding the regime's full removal) depends upon how wartime experiences of violence are framed. Specifically, participants were randomly assigned to one of four prime conditions:

A. Family suffering: 'As we've discussed, you and your family have lost and suffered through a lot during this conflict.'

B. Community suffering: 'I don't need to tell you, your community has lost an enormous amount and suffered considerably since the war began.'

C. Community sacrifice: 'I don't need to tell you, a lot of people, possibly some from your own community, have fought hard and sacrificed a lot to get to this point.'

D. Original motives: 'Recalling for a moment what motivations led people such as you or members of your community to initially want a change and try to make a better Syria, what would you say the main reason was?'

After the prime, participants were then asked 'Given this, what kind of political settlement do you think the leadership that most closely represents you should accept in order to put an end to the violence?', with four answer options:

1. Accept a peace settlement that ends the fighting, regardless of who maintains control.

2. Accept a peace settlement that ends the fighting, but only if Syria becomes a federal country with some areas outside of the Assad regime's control. 
3. Accept a peace settlement that ends the fighting, but only if the regime is removed entirely from Syria.

4. No political settlement is acceptable, fighting should continue until a outright military victory.

We note that one challenge with this question is that there is no natural 'control condition.' Respondents have some mental state and information in mind at the time of questioning. We thus must rely on comparisons between conditions - for example, comparing attitudes under the Community suffering prime to outcomes under the Community sacrifice prime - to ascertain whether attitudes depend on the prime, and the relative differences between any two primes.

Finally, to study whether these primes also influence reported beliefs about the potential for (opposition) victory in the conflict, we also ask our respondents to assess the likelihood of opposition victory (very likely, somewhat likely, chances are even, somewhat unlikely, or very unlikely). We map these to probabilities $0, .25, .5, .75$, and 1 for purposes of simple and interpretable analysis below.

\subsection{Hypotheses}

In Experiment 1, we are first interested in whether support for a ceasefire is higher when a Syrian civilian proposes it, than when either opposition or regime commanders propose it. Second, to examine whether high agreement with a civilian proposal is really just high agreement with somebody presumed to take an opposition proposition, we look to the sub-sample of respondents who explicitly reported that they identify with the opposition, thereby allowing us to determine if support for a Syrian civilian-proposed ceasefire remains higher than a Syrian opposition commander-proposed ceasefire even within this group. We thus explore:

H1a: Respondents are more likely to favor a ceasefire when it is proposed by a Syrian civilian than when it is proposed by a Syrian military elite from either side (regime or opposition).

H1b: Even respondents who report that 'the opposition most closely represents them' are more likely to support a ceasefire proposed by a Syrian civilian than one proposed by a Syrian opposition commander.

For Experiment 2, our key comparisons aim first to determine if willingness to settle with the regime varies depending on whether violence is framed as community sacrifice, community suffering, family suffering, or a prime to recall the original motives for the uprising. ${ }^{10}$ We are further interested in whether the effect of sacrifice versus suffering is sustained in communities that experience the most violence and thus may have the most hardened attitudes. We thus examine:

H2a: Approval of settlements with the regime will be lower when violence is framed as Community sacrifice than when framed as Community suffering.

\footnotetext{
${ }^{10}$ When asked what they believe the original motives for the rebellion were, the most common responses were: to stand against oppression or tyranny (42\%); to stand against the regime or the Assad regime (33\%), to stand against disorder (8\%), to stand for freedom (4\%), and to stand corruption $(3 \%)$.
} 
H2b: Approval of settlements with the regime will be lower when violence is framed as Community sacrifice than when framed as Family suffering.

H2c: A prime to recall the original motives will not detectably alter approval for settlement compared to Community sacrifice.

H3: Among respondents from neighborhoods that have suffered deaths and injuries, approval of settlement with the regime will be lower when violence is framed as Community sacrifice, than when framed as Community suffering (H3a) or as Family suffering (H3b).

Finally, in Section 3.2 we described 'perceived chances of opposition victory' as an additional outcome variables in Experiment 2. Our aim in adding this is to better understand the impact of the sacrifice versus suffering framings mechanistically, by examining whether this framing also appears to influence participants' 'optimism' about opposition victory. Thus a fourth and final hypothesis to examine is

H4: Violence framed as community sacrifice will make respondents more optimistic about the likelihood of an opposition victory against the incumbent regime.

\subsection{Estimation procedures}

For both experiments, because the primes are randomized, no adjustment or conditioning is required, and we simply conduct difference-in-means tests allowing unequal variance. We present randomization checks in the Appendix.

\section{Results}

\subsection{Descriptive statistics}

We begin by briefly describing our respondents' attitudes about war termination, and how they relate observationally to their exposure to violence during the civil war in Syria. The Appendix provides a detailed description of the questions in the survey instrument used to construct these variables.

Table I provides means on a number of variables. The first group gives the proportion of the sample choosing each of various proposed conflict outcomes as 'preferred' ${ }^{11}$ The next group asks which outcomes participants expect. Finally, we also show the proportion of respondents who say they will not return to Syria. As expected, our sample is heavily pro-opposition, as the mean values for the political attitude variables shows. About $81 \%$ of the sample sees Assad's removal as a preferred resolution to the conflict, while only $24 \%$ sees settlement with Assad as a preferred outcome. It is also worth noting that the level of support for federation and partition is very low, about $4 \%$. Finally, only $8 \%$ of our sample does not want to return to Syria under any circumstances. Hence, our sample consists of individuals who eventually plan to return to Syria, and may thereby play a role

\footnotetext{
${ }^{11}$ The translation of 'preferred' in this case connotes 'a good outcome', not the single best outcome. Hence participants can choose more than one outcome, as indicated by the variable 'Total endings chosen'.
} 
Table I. Political attitudes

\begin{tabular}{lcc}
\hline Question & $\mathrm{N}$ & Mean \\
\hline Preferred ending: & & \\
Settlement with Assad & 1,027 & 0.24 \\
Removal of Assad & 1,036 & 0.81 \\
Demilitarization & 1,009 & 0.56 \\
Federation & 1,023 & 0.04 \\
Partition & 1,047 & 0.04 \\
Total endings chosen & 961 & 1.68 \\
\hline Expected ending: & & \\
Settlement with Assad & 1,003 & 0.23 \\
Removal of Assad & 967 & 0.80 \\
Demilitarization & 947 & 0.57 \\
Partition & 945 & 0.07 \\
Federation & 916 & 0.03 \\
Total endings expected & 876 & 1.70 \\
\hline Other: & & \\
Will not return to Syria & 1,083 & 0.08 \\
\hline
\end{tabular}

Mean values for a set of political attitudes asked in the survey. The number of observations differs because of missing values.

in the future of the country. This makes learning about their political attitudes towards negotiated settlement and compromise, and how these attitudes can be affected, critically important.

\subsection{Experiment 1: Civilian versus military proposers}

For the analysis of Experiment 1, we simply collapse response categories into an agree category (including 'strongly'- or 'somewhat agree') and a disagree category (including 'somewhat'- or 'strongly disagree'). We also collapse the two Syrian civilian messenger primes (a civilian non-combatant who has lost a limb during the war, and a civilian noncombatant) into one 'civilian' category. ${ }^{12}$

Figure 3 shows the proportion who agree to a ceasefire, with $95 \%$ confidence intervals for each prime category. Hypothesis 1a was that respondents will be more in favor of ceasefire when it is another Syrian civilian calling for it as opposed to when a military elite calls for it. We see this clearly: respondents are 11 percentage points more likely to agree to a ceasefire and peaceful negotiations when it is put forth by a fellow civilian than by a Syrian government commander $(p=0.002)$, and 14 percentage points more likely than when an opposition commander makes the proposal $(p<0.001)$.

Moving to hypothesis 1b, we note that our sample mostly consists of respondents who self-identify as pro-opposition, though there is a sizable minority who thinks that no side in the conflict represents them. ${ }^{13}$ One possible explanation for the positive effect of the

\footnotetext{
${ }^{12}$ Our results remain substantially unchanged if we keep these primes separate - the two groups are statistically indistinguishable, so collapsing them together aids in achieving statistical power.

${ }^{13}$ We asked in the survey which group in the conflict most closely represents the interests of the respondent. $72 \%$ say it is the opposition, while the rest almost exclusively says 'no one'. Fewer than $0.5 \%$ said Assad's
} 
Syrian civilian proposer relative to even the opposition commander is that it is driven by the large minority of respondents in our sample who do not think that the opposition groups represent them. Hypothesis 1b thus asks: even among those individuals who identify closely with the opposition, do we still see higher support for the civilian-proposed arrangement than the one proposed by an opposition commander? Figure 4 shows results under each prime, now restricted to those who report identifying with opposition groups in Syria. Proposals made by a Syrian civilian draw greater support than those made by an opposition commander even in this subset of respondents that might be expected to be most sympathetic to proposals made by the opposition commanders.

The persuasive effect of civilian proposals is consistent with the varied theoretical motivations described above for attempting this manipulation. Seeing a Syrian civilian propose an agreement may assure the respondent that agreeing to such a position will not be viewed as violating the group's expectations, or worse, as raising suspicion of sympathies with the enemy. Alternatively, respondents may simply be influenced by civilians rather than elites because, whomever they imagine this unnamed civilian to be, they are much more similar (e.g. Turner \& Oakes, 1998), and likely have a more common plight than can be said of military elites. That said, as we do not know who our respondents imagine the civilian in our prompts to be, a number of open questions remain that we discuss in Section 5.

We next study how the framing of those violent experiences themselves influence willingness to compromise with the incumbent Assad regime.

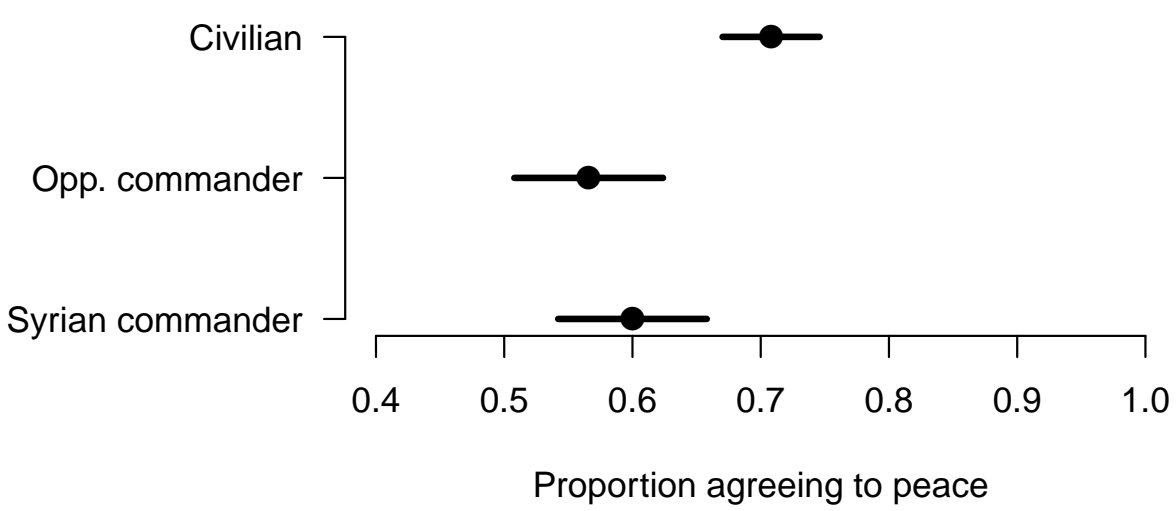

Figure 3. Effect of proposer on agreement to a ceasefire.

Proportion of respondents willing to agree to 'laying down arms and returning to a non-violent political process', conveyed by either a civilian (Civilian) - collapsing together injured and non-injured civilians - an opposition commander (Opp. commander) or a commander with the government (Syrian commander). Whiskers show 95\% confidence intervals. Agreements proposed by civilians are more likely to be accepted than those proposed by commanders from either side.

government represents them. 


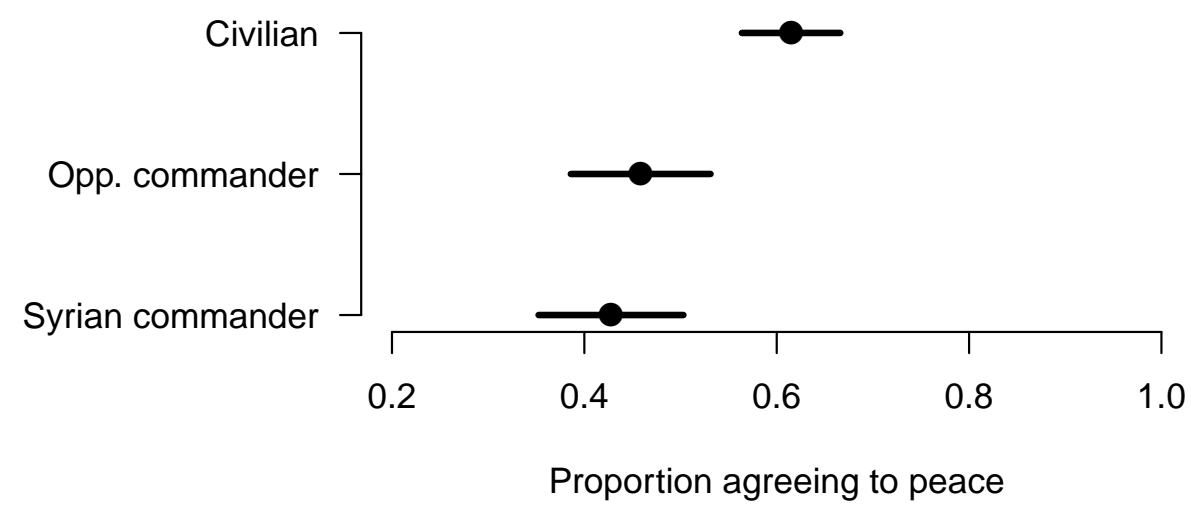

Figure 4. Effect of proposer on agreement to a ceasefire (only pro-opposition respondents).

Proportion of respondents willing to agree to 'laying down arms and returning to a non-violent political process', conveyed by either a civilian (Civilian), an opposition commander (Opp. commander), or a commander with the government (Syrian commander). Restricted to those who say opposition groups represent their interests. Whiskers show $95 \%$ confidence intervals.

\subsection{Experiment 2: Framing wartime experiences}

For analysis of Experiment 2, the outcome is coded as a 1 for participants that are willing to settle in some way with the regime to achieve peace (accepting a peace settlement regardless of who maintains control, or accepting a peace settlement that leaves some parts of the country under the Assad regime's control). It is thus coded as 0 for the outcomes that do not involve any settling or compromise, insisting on removing the regime entirely. It therefore encodes whether the respondent is willing to accept any settlement with the Assad regime, versus demanding a future that leaves the regime with no power. We then simply compute conditional means for this outcome variable by prime, which are shown with $95 \%$ confidence intervals in Figure 5.

Hypotheses 2a-2c are analyzed in Figure 5. Violence framed as Community sacrifice made respondents less willing to settle with the regime compared to violence framed as Community suffering or Family suffering. Specifically, compared to those in the sacrifice condition, those in the Community suffering and Family suffering condition were 18 percentage points $(p<0.001)$ and 14 percentage points $(p<0.001)(\mathrm{H} 2 \mathrm{~b})$ more likely to approve of a settlement with the regime.

Finally, the prime to recall the original motives of the conflict produces a level of willingness marginally higher than Community sacrifice ( 8 percentage points, $p=0.054$ ) (H2c), though still considerably lower than Community suffering (10 percentage points, $p=0.02)$. A prime to recall the original motives thus falls squarely in between the 'sacrifice' and the 'suffering' primes in terms of willingness to settle.

Next, it could be either that prior experience with the types of violent harms we reference makes the primes more salient, or that prior experience hardens attitudes, thus making them unlikely to be influenced by such primes. To examine this, we split the sample according to whether individuals report that members of their neighborhood were 


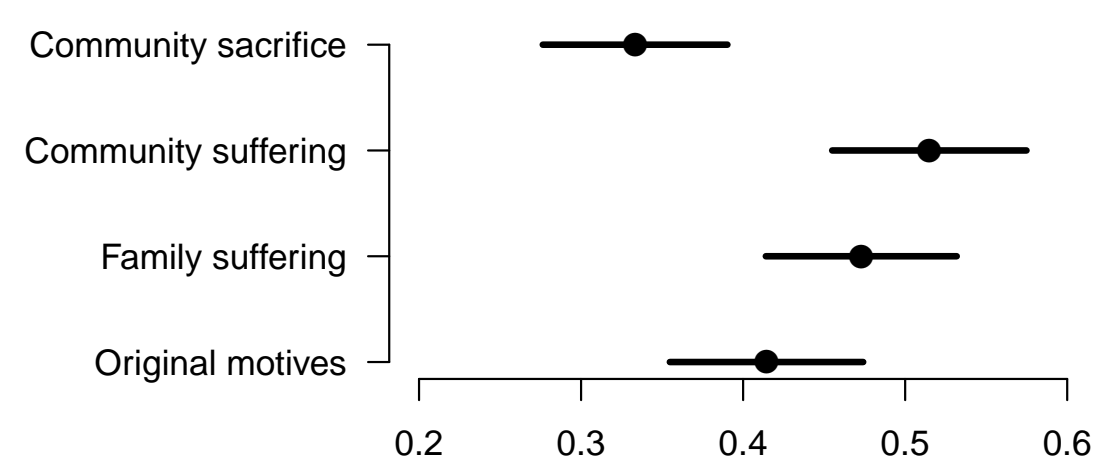

Proportion willing to compromise with the regime

Figure 5. Effects of primes on willingness to settle

Results of survey experiment on framing of losses. The outcome is 1 if participants accept a deal that settles with the regime, leaving it some power; it is 0 if they accept only outcomes that entirely remove the regime from power. Estimates show effect of each prime, relative to a prime reminding participants of the original motives for the rebellion.

injured or killed in the conflict (H3). Figure 6 shows results similar to Figure 5 but on these split samples. Among those who did have neighbors injured or killed ('neighborhood hurt'), compared to the Community sacrifice prime, willingness to settle was 24 percentage points higher among those primed to Community suffering, and 27 percentage points higher among those primed to Family suffering. These point estimates are indeed larger (though not significantly so) than the corresponding effects in the sample without neighborhood members injured or killed (18 and 7 percentage points, respectively).

We thus find that prior experience with community loss does not detectably weaken, and may actually enhance, the effect of these primes on willingness to settle. It is also worth noticing that, while not a causally identified comparison, the overall willingness to settle is higher among those from the neighborhoods that have experienced losses.

Neighborhood hurt

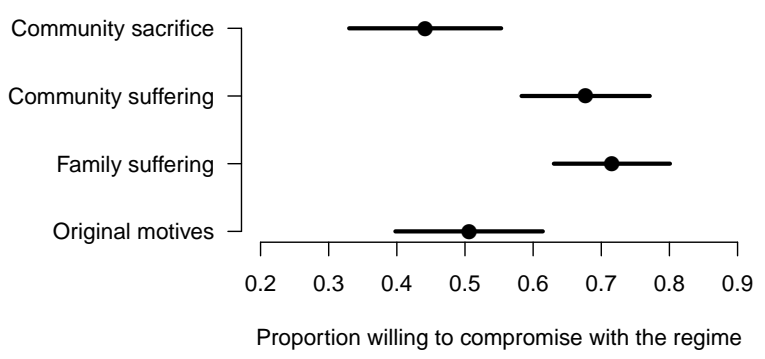

Neighborhood not hurt

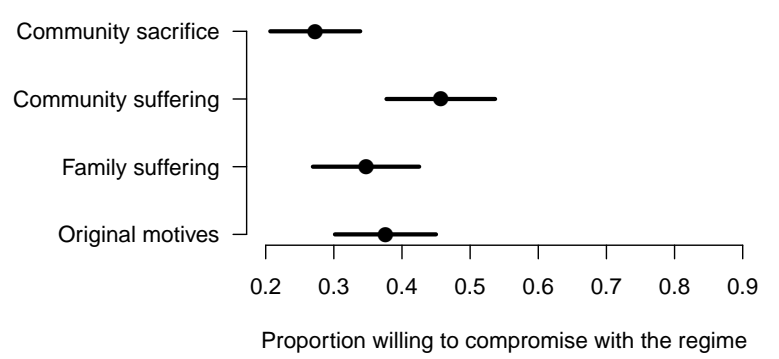

Figure 6. Effect of sacrifice/suffering primes, by neighborhood exposure to violence

Results of survey experiment on framing of losses separately for those with members of their neighborhood who were injured or killed (left, $\mathrm{N}=376$ ) and those who have no injured or killed members of their neighborhood (right, $\mathrm{N}=659$ ). The outcome is one if participants accept a peace settlement that does not require defeat/removal of the regime, or zero if they accept only outcomes that entirely remove the regime from power 
Finally, while we do not theorize about the role of these primes in affecting beliefs about the prospects for opposition victory, we are well positioned to explore this, and it suggests a possible mechanism by which these primes might influence willingness to settle. Figure 7 provides an exploration of Hypothesis 4. The same primes that generated the lowest willingness to settle (i.e. Community sacrifice) in prior analysis generate the highest optimism regarding the likelihood of victory for the opposition. Specifically, optimism for an opposition victory under the Community sacrifice prime is 7 percentage points higher $(p=0.002)$ than under the Community suffering prime, and 10 percentage points higher $(p<0.001)$ under the family suffering prime. The difference between Community sacrifice and Original motives is not significant at 4 percentage points $(p=0.13)$.

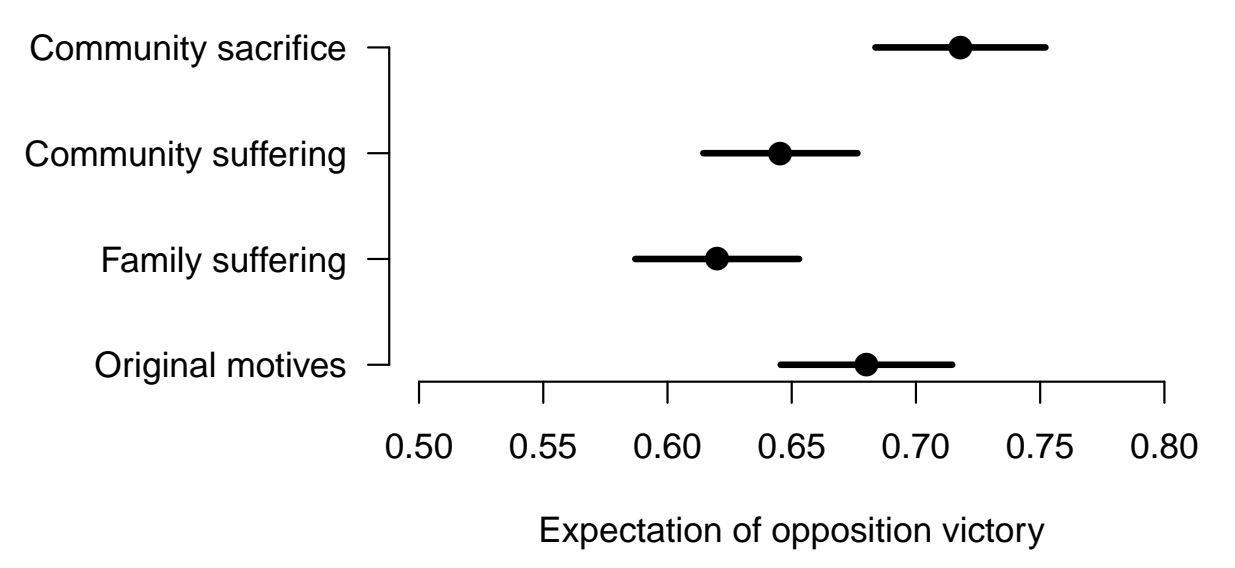

Figure 7. Expectation of opposition victory depending on framing of loss

Mean probability that the opposition will defeat the regime, by prime. Optimism that the opposition will defeat the regime is far higher under the Community sacrifice prime than either Community suffering or Family suffering prime.

This result suggests that framing violence as sacrifice not only increases demands for removal of Assad, but also increases optimism regarding the likelihood of this outcome. This raises an interesting question to be pursued in future work: does the Community sacrifice prime, which emphasizes sunk costs, increase demands for victory because it alters the way respondents view conflict odds, making them more optimistic that victory is actually possible? Or does the prime simply increase demands for victory, after which participants later say they are more optimistic about that victory in order to maintain internal consistency? Or is a third factor responsible for both? Whatever the causal ordering, the surprisingly large effects of such subtle primes on both the optimism and demand for Assad's complete removal from power suggests that the social framing of losses can powerfully alter the policies refugees will support to terminate conflicts.

\section{Discussion and conclusions}

Civil conflicts are the dominant form of war, giving rise to death, mass displacement, extremism and illicit economic activity well beyond the war theater (Melander, Pettersson 
\& Themnér, 2016). While political and military elites will strike bargains, settlements that achieve lasting peace require buy-in from civilian communities, including refugees. The effects of wartime experiences on civilian attitudes towards settlements - especially in conflicts where the objective is not to control the population but to remove it - are not well understood. Although one may expect experiences with violence to produce obdurate attitudes regarding the acceptability of peaceful settlements, we instead find surprising flexibility in these attitudes. Specifically, we find that the identity of the person proposing a ceasefire, and narratives that frame past violence can both strongly influence the compromises refugees are willing to accept to end fighting.

When a ceasefire is proposed by a Syrian civilian, it is deemed acceptable far more often than when proposed by military elites from either side. This finding is interesting for several reasons. First, elites - especially armed ones - are typically viewed as the key actors in securing peace settlements: they sit at the negotiating table, command their forces, and are often assumed to influence civilians' disposition towards who is an enemy or an ally. Yet, in this particular group of refugees in Turkey, civilian voices more effectively persuade our respondents to accept a ceasefire and return to peaceful negotiations. This holds even among respondents who identify most closely with the opposition, suggesting it does not merely reflect persuasion by those with similar political leanings.

These results are consistent with several theoretical positions. First, under uncertainty, civilians may look for information or evidence from fellow civilians, who can reasonably be assumed to be more similar to the respondent than can be said of military commanders on either side. Or, civilians may worry that expressing a desire for peace will violate community expectations or raise suspicion - both of which can be allayed by a Syrian civilian being the one to propose the agreement. Alternatively, after suffering so much violence, civilians may also simply be wary of proposals made by armed actors on either side.

We note that our prompt naming a civilian as the proposer of peace was not specific, and thus we do not know what sort of civilian our respondents imagine this proposer to be. This has consequences for the applicability of 'similarity-based influence' theories we cited above. On the one hand, it may be that the generality of the prime does not much matter: regardless of the particular type of civilian imagined by the respondent, any civilian is much more like the respondent than a military commander is. On the other hand, interesting heterogeneity may go unnoticed in this design. It is possible that certain civilian types would be more persuasive than others, such as civilians who are also refugees in Turkey, or at least known to be pro-opposition, as compared to those who are still in Syria or support the regime. If so, the persuasive effects of having a civilian propose an agreement could potentially be much largely in some cases than the average we see here. Future research could usefully examine how these finer features of a civilian endorser's identity alter their influence.

There is an ongoing debate about the importance and effectiveness of including civilian actors' in these negotiations (Nilsson, 2018; Zanker, 2014). Our finding that a civilianproposed ceasefire elicits greater support is particularly informative in this case, where one might expect nothing to move refugee attitudes given the horrific forms of violence they 
have endured. This suggests it is reasonable to expect a similar or even greater ability of civilian-proposals to influence attitudes among those who have experienced less severe violence.

Our second main finding is that wartime experience characterized as sacrifice makes respondents more likely to call for outright victory against the regime, whereas characterizing these experiences as suffering heightens their willingness to agree to settlements allowing the regime to retain some power. This holds among those who report experiencing greater harm, who might be most expected to have firm preferences. Again these results are consistent with several theoretical accounts. The word 'sacrifice' may engage an escalation of commitment in participants' thinking, making the idea of 'giving up' (by agreeing to a settlement with Assad) less palatable. It may also lead respondents to feel that settling would be seen as a betrayal of the community and what it has fought for. By comparison, the word 'suffering' may raise the salience of how the violence has harmed individuals, their families, and their communities, without emphasizing what was intended to be gained. This may engage heightened 'weariness' and a desire to see violence come to an end. These primes also have an effect on reported optimism regarding prospects for an opposition victory. Respondents primed to think about their wartime experience as sacrifice were more optimistic that the opposition will be victorious over the regime, compared to those primed to think of these experiences as suffering. Future research would be required to claim any causal ordering of these effects: It could be that this increased optimism a) leads to a lower willingness to settle; b) that the lower willingness to settle comes first and participants update their optimism in order to maintain consistency; or that c) some other effect of the primes leads to both outcomes.

Finally, our findings also have practical implications for efforts to end conflicts through lasting settlements. Experiment 1 suggests that focusing negotiations entirely around armed elites may be unproductive, as they are less able to persuade the broader population that such a settlement is desirable, potentially paving the way for new violence entrepreneurs to mobilize. Inclusion of civilians in peace processes, by contrast, can aid in ensuring broader support for such arrangements once reached. Second, our finding that willingness to settle is strongly influenced by the framing of wartime experiences - as sacrifice or as suffering - suggests that public discussion and dialogues may help or hinder in preparing for the way for peace, depending upon which of these narratives are emphasized.

\section{Replication statement}

The dataset, survey, and $\mathrm{R}$ files required to replicate these results, along with the online appendix, can be found at http://www.prio.org/jpr/datasets. 


\section{References}

Alzoubi, Zedoun (2017) Syrian civil society during the peace talks in geneva: Role and challenges. New England Journal of Public Policy 29(1): 1-4.

Araabi, Samer \& Leila Hilal (2016) Reconciliation, reward, and revenge: Analyzing syrian deescalation dynamics through local ceasefire negotiations (http://www.berghof-foundation.org/fileadmin/redaktion/Publications/Papers/ AraabiHilal_SyrianLocalCeasefireNegotiations.pdf).

Arkes, Hal R \& Catherine Blumer (1985) The psychology of sunk cost. Organizational behavior and human decision processes 35(1): 124-140.

Balcells, Laia (2012) The consequences of victimization on political identities. evidence from spain. Politics and Society 40(3): 309-345.

Bauer, Michal; Christopher Blattman, Julie Chytilová, Joseph Henrich, Edward Miguel \& Tamar Mitts (2016) Can war foster cooperation? The Journal of Economic Perspectives 30(3): 249-274.

Boettcher III, William A \& Michael D Cobb (2009) Don't let them die in vain: Casualty frames and public tolerance for escalating commitment in iraq. Journal of Conflict Resolution 53(5): 677-697.

Canetti, Daphna; Julia Elad-Strenger, Iris Lavi, Dana Guy \& Daniel Bar-Tal (2017) Exposure to violence, ethos of conflict, and support for compromise: Surveys in Israel, East Jerusalem, West Bank, and Gaza. Journal of Conflict Resolution 61(1): 84-113.

Christia, Fotini (2012) Alliance formation in civil wars. Cambridge University Press.

Cialdini, Robert (2001) Harnessing the science of persuasion. Harvard Business Review: $72-81$.

Collier, Paul \& Anke Hoeffler (2004) Greed and grievance in civil war. Oxford Economic Papers 56: 563-95.

Corstange, Daniel \& Erin York (2018) Sectarian framing in the syrian civil war. American Journal of Political Science 62(2): 441-455.

Dean, Roger (2015) Remittances to Syria: What works, where, and how (https://reliefweb.int/sites/reliefweb.int/files/resources/ 2015-07-nrc---remittances-to-syria---report-final-\%281\%29.pdf).

Dietz-Uhler, Beth (1996) The escalation of commitment in political decision-making groups: A social identity approach. European Journal of Social Psychology 26(4): 611-629.

Elu, Juliet \& Gregory N. Price (2012) Remittances and the financing of terrorism in subSaharan Africa: 1974-2006. Peace Economics, Peace Science and Public Policy 18(1): $1-40$. 
Erdogan, Murat (2017) Syrians barometer (https://mmuraterdogan.files.wordpress.com/ 2016/06/syrians-barometer-executive-summary.pdf).

Fearon, James D. \& David D Latin (2008) Civil war termination. Unpublished manuscript.

Gayer, Corinna Carmen; Shiri Landman, Eran Halperin \& Daniel Bar-Tal (2009) Overcoming psychological barriers to peaceful conflict resolution: The role of arguments about losses. Journal of Conflict Resolution 53(6): 951-975.

Getmansky, Anna; Tolga Sinmazdemir \& Thomas Zeitzoff (2018) Refugees, xenophobia, and domestic conflict: Evidence from a survey experiment in turkey. Journal of Peace Research 55(4): 491-507.

Ghosn, Faten; Alex Braithwaite \& Tiffany S. Chu (2019) Violence, displacement, contact, and attitudes toward hosting refugees. Journal of Peace Research 56(X): XX-XX.

Grossman, Guy; Devorah Manekin \& Dan Miodownik (2015) The political legacies of combat: Attitudes toward war and peace among israeli ex-combatants. International Organization 69(4): 981-1009.

Hartzell, Caroline A. (2018) Civil war termination. In: William R. Thompson (ed.) The Oxford Encyclopedia of Empirical International Relations Theory. Oxford University Press.

Hazlett, Chad Angry or weary? The effect of physical violence on attitudes towards peace in Darfur. (https://www.researchgate.net/publication/326693532_Angry_ or_Weary_The_effect_of_physical_violence_on_attitudes_towards_peace_in_Darfur).

Hirsch-Hoefler, Sivan; Daphna Canetti, Carmit Rapaport \& Stevan E Hobfoll (2016) Conflict will harden your heart: Exposure to violence, psychological distress, and peace barriers in israel and palestine. British Journal of Political Science 46(4): 845-859.

Hurwitz, Jon (1989) Presidential leadership and public followership. Manipulating public opinion: Essays on public opinion as a dependent variable: 222-50.

Kahneman, Daniel \& Amos Tversky (1984) Choices, values, and frames. American Psychologist 39(4): 341-350.

Kalyvas, Stathis (2018) Jihadi rebels in civil war. Daedalus 147(1): 26-47.

Kalyvas, Stathis N (2006) The logic of violence in civil war. Cambridge Univ Press.

Karakus, Dogukan Cansin \& Isak Svensson (2017) Between the bombs: Exploring partial ceasefires in the syrian civil war, 2011-2017. Terrorism and Political Violence: 1-20.

Kirişci, Kemal (2014) Syrian refugees and Turkey's challenges: Going beyond hospitality. Brookings Washington, DC.

Kydd, Andrew H. \& Barbara F. Walter (2002) Sabotaging the peace: The politics of extremist violence. International Organization 56(2). 
Levy, Jack S (1992) An introduction to prospect theory. Political Psychology: 171-186.

Levy, Jack S \& T Clifton Morgan (1986) The war-weariness hypothesis: An empirical test. American Journal of Political Science: 26-49.

Lynch, March (2016) The New Arab Wars: Uprisings and Anarchy in the Middle East. Public Affairs.

Maoz, Zeev (1990) Framing the national interest: The manipulation of foreign policy decisions in group settings. World Politics 43(1): 77-110.

McDermott, Rose (2004) Prospect theory in political science: Gains and losses from the first decade. Political Psychology 25(2): 289-312.

Melander, Erik; Therése Pettersson \& Lotta Themnér (2016) Organized violence, 19892015. Journal of Peace Research 53(5): 217-242.

Morjé Howard, Lise \& Alexandra Stark (2017) How civil wars end: The international system, norms, and the role of external actors. International Security 42(3): 127-171.

Newman, Edward \& Oliver P. Richmond (2006) Obstacles to peace processes: Understanding spoiling. In: Edward Newman \& Oliver P. Richmond (eds) Challenges to Peacebuilding: Managing Spoilers During Conflict Resolution. United Nations University Press.

Nilsson, Manuela (2018) Civil society actors in peace negotiations in central america. Journal of Civil Society 14(2): 135-152.

Nisbett, Richard E \& Dov Cohen (1996) Culture of honor: the psychology of violence in the south. Westview Press, Boulder CO.

Petersen, Roger D (2002) Understanding ethnic violence: Fear, hatred, and resentment in twentieth-century Eastern Europe. Cambridge University Press.

Regan, Patrick M. \& Richard W. Frank (2014) Migrant remittances and the onset of civil war. Conflict Management and Peace Science 31(5): 502-20.

Salehyan, Idean (2007) Transnational rebels: Neighboring states as sanctuary for rebel groups. World Politics 59(2): 217-242.

Salehyan, Idean (2009) Rebels without borders: transnational insurgencies in world politics. Cornell University Press.

Salehyan, Idean \& Kristian Gleditsch (2006) Refugees and the spread of civil war. International Organization 60(2): 335-366.

Scheufele, Dietram A \& Shanto Iyengar (2012) The state of framing research: A call for new directions. The Oxford Handbook of Political Communication Theories. New York: Oxford University Press.

Scheufele, Dietram A \& David Tewksbury (2007) Framing, agenda setting, and priming: The evolution of three media effects models. Journal of communication 57(1): 9-20. 
Schon, Justin (2019) Motivation and opportunity for conflict-induced migration: An analysis of syrian migration timing. Journal of Peace Research 56(X): XX-XX.

Schott, John Paul; Laura D Scherer \& Alan J Lambert (2011) Casualties of war and sunk costs: Implications for attitude change and persuasion. Journal of Experimental Social Psychology 47(6): 1134-1145.

Staw, Barry M (1976) Knee-deep in the big muddy: A study of escalating commitment to a chosen course of action. Organizational behavior and human performance 16(1): $27-44$.

Stedman, John J (1997) Spoiler problems in peace processes. International Security 22(2): $5-53$.

Tellez, Juan Fernando (2018) Worlds apart: Conflict exposure and preferences for peace. Journal of Conflict Resolution: 1-24.

Tezcür, Güneş Murat (2016) Ordinary people, extraordinary risks: Participation in an ethnic rebellion. American Political Science Review 110(2): 247-264.

Thaler, Richard H \& Eric J Johnson (1990) Gambling with the house money and trying to break even: The effects of prior outcomes on risky choice. Management Science 36(6): 643-660.

Toft, Monica (2009) Securing the Peace: The Durable Settlement of Civil Wars. Princeton University Press, Princeton NJ.

Turner, J.C. (1991) Social Influence. Open University Press.

Turner, J. C. \& P. J Oakes (1998) Self-categorization theory and social influence. In: P. B. Paulus (ed.) The Psychology of Group Influence (2nd ed.). Erlbaum Publishing, 233-275.

Varshney, Ashutosh (2003) Ethnic conflict and civic life: Hindus and Muslims in India. Yale University Press, New Haven CT.

Weber, Martin \& Heiko Zuchel (2005) How do prior outcomes affect risk attitude? comparing escalation of commitment and the house-money effect. Decision Analysis 2(1): $30-43$.

Wood, Elisabeth Jean (2003) Insurgent collective action and civil war in El Salvador. Cambridge University Press.

Zaller, John (1992) The nature and origins of mass opinion. Cambridge University Press.

Zanker, Franzisca (2014) Legitimate representation: Civil society actors in peace negotiations revisited. International Negotiation 19(1): 62-88.

Zena, Tahhan (2017) The voices missing from Syria's peace talks. (http://www.aljazeera.com/indepth/features/2017/03/ syria-war-missing-voices-syria-peace-talks-170322073131728.html). 
Åkebo, Malin (2016) Ceasefire Agreements and Peace Processes: A Comparative Study. Routledge.

\section{Biographical Statement}

KRISTIN FABBE, b. 1979, PhD in Political Science (MIT 2012). Assistant Professor, Harvard Business School (2015- ). Current research interests: identity politics, forced migration, Middle East politics.

CHAD HAZLETT, b. 1979, PhD in Political Science (MIT, 2014). Assistant Professor in Statistics and Political Science, UCLA (2014- ). Current research interests: causal inference with observational data, civil war and mass atrocity, and effects of violence on attitudes.

TOLGA SINMAZDEMIR, b. 1980, PhD in Politics (New York University, 2012); Postdoctoral Fellow at Washington University, St. Louis (2012-13); Assistant Professor, Department of Political Science and International Relations, Bogazici University (2013-18); Fellow, London School of Economics (2018- ). Current research interests: causes and consequences of political conflict and violence, with a special focus on the Middle East. 